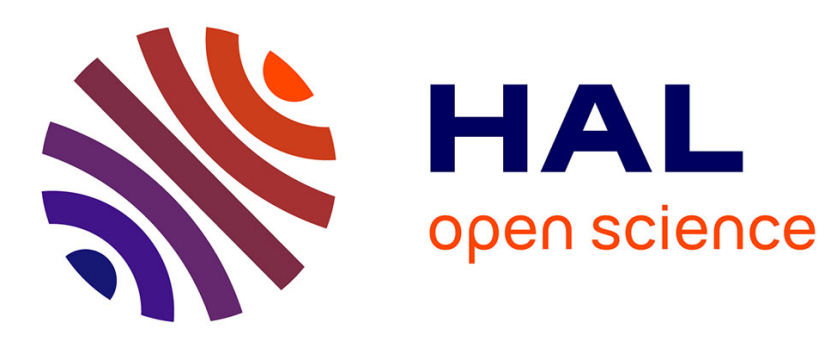

\title{
Kinetics of hepatic phase I and II biotransformation reactions in 8 finfish species
}

Jaime Fernando González M., Renate Reimschuessel, Badar Shaikh, Andrew S. Kane

\section{- To cite this version:}

Jaime Fernando González M., Renate Reimschuessel, Badar Shaikh, Andrew S. Kane. Kinetics of hepatic phase I and II biotransformation reactions in 8 finfish species. Marine Environmental Research, 2009, 67 (4-5), pp.183. 10.1016/j.marenvres.2009.01.002 . hal-00563069

\section{HAL Id: hal-00563069 \\ https://hal.science/hal-00563069}

Submitted on 4 Feb 2011

HAL is a multi-disciplinary open access archive for the deposit and dissemination of scientific research documents, whether they are published or not. The documents may come from teaching and research institutions in France or abroad, or from public or private research centers.
L'archive ouverte pluridisciplinaire HAL, est destinée au dépôt et à la diffusion de documents scientifiques de niveau recherche, publiés ou non, émanant des établissements d'enseignement et de recherche français ou étrangers, des laboratoires publics ou privés. 


\section{Accepted Manuscript}

Kinetics of hepatic phase I and II biotransformation reactions in 8 finfish species

Jaime Fernando González M., Renate Reimschuessel, Badar Shaikh, Andrew S. Kane

PII:

S0141-1136(09)00004-X

DOI:

10.1016/j.marenvres.2009.01.002

Reference:

MERE 3315

To appear in:

Marine Environmental Research

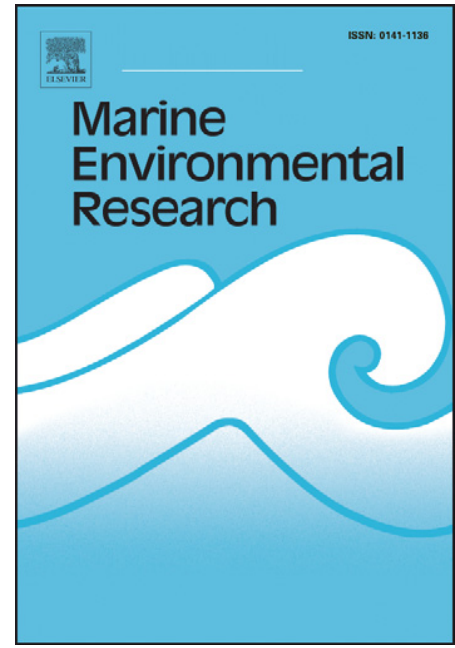

Received Date: $\quad 13$ October 2008

Revised Date: $\quad 5$ January 2009

Accepted Date: $\quad$ 11 January 2009

Please cite this article as: González M., J.F., Reimschuessel, R., Shaikh, B., Kane, A.S., Kinetics of hepatic phase I and II biotransformation reactions in 8 finfish species, Marine Environmental Research (2009), doi: 10.1016/ j.marenvres.2009.01.002

This is a PDF file of an unedited manuscript that has been accepted for publication. As a service to our customers we are providing this early version of the manuscript. The manuscript will undergo copyediting, typesetting, and review of the resulting proof before it is published in its final form. Please note that during the production process errors may be discovered which could affect the content, and all legal disclaimers that apply to the journal pertain. 


\section{Kinetics of hepatic phase I and II biotransformation reactions in 8 finfish species}

Jaime Fernando González M. , School of Veterinary Medicine \& Animal Science Universidad Nacional de Colombia, Bogotá - Colombia.

Renate Reimschuessel, Center for Veterinary Medicine - Food Drug Administration (USFDA), Laurel (MD) - USA

Badar Shaikh, Center for Veterinary Medicine - Food Drug Administration (USFDA), Laurel (MD) - USA

Andrew S. Kane, College of Public Health \& Health Professions -

University of Florida, Gainesville (FA) - USA

* Author to whom correspondence and proofs should be addressed:

J.F. González

Postal address: Calle 23 A No. 59-72 T4 Ap 704 Bogotá (Colombia)

Phone number: +5713165524

Fax number: $\quad+5713165401$

e-mail: jfgonzalezma@unal.edu.co, jaimefgonzalez@gmail.com 


\begin{abstract}
Hepatic microsomes and cytosols of channel catfish (Ictalurus punctatus), rainbow trout (Oncorhynchus mykiss), Atlantic salmon (Salmo salar), red tilapia (Oreochromis sp.), largemouth bass (Micropterus salmoides), striped bass (Morone saxatilis), hybrid striped bass (Morone saxatilis x Morone crysops), and bluegill (Lepomis macrochuris) $(\mathrm{n}=8)$ were used to study the kinetics of phase I (ECOD, EROD, PROD, BROD) and phase II (UDP-glucuronosyltransferase (UDPGT)-, sulfotransferase (ST)- and glutathione-s-transferase (GST)- mediated) reactions. The best catalytic efficiency for ECOD and GST activities was performed by channel catfish, Atlantic salmon, rainbow trout and tilapia. The highest EROD catalytic efficiency was for Atlantic salmon. None of the species had either PROD or BROD activities. Rainbow trout had very similar UDPGT catalytic efficiency to tilapia, channel catfish, Atlantic salmon, largemouth bass and bluegill. Sulfotransferase conjugation had no significant differences among the species. In summary, tilapia, channel catfish, Atlantic salmon and rainbow trout had the best biotranforming capabilities; striped bass, hybrid striped bass and bluegill were low metabolizers and largemouth bass shared some capabilities with both groups.
\end{abstract}

Keywords: hepatic, phase I and II biotransformation reactions, finfish 


\section{ACCEPTED MANUSCRIPT}

\section{Introduction}

Phase I and II biotransformation reactions are of great importance to understand metabolism of endogenous molecules as well as transformation of xenobiotics and drugs in fish and other species (Mansui, 1998; Nelson, 1998; Mortensen and Arukwe, 2007; Reynaud et al., 2008; Arukwe et al., 2008). However, biotransformation profiles are still unknown in several fish species of importance in aquaculture or as environmental bioindicators. Investigating these biotransformation profiles may help to understand capabilities, similarities and differences of these fish species to metabolize endogenous substrates, drugs and pollutants.

The substrates 7-ethoxycoumarin, 7-ethoxyresorufin, 7-pentoxyresorufin, 7-benzyloxyresorufin, resorufin and 1-chloro-2,4-dinitrobenzene are some of the model compounds used to investigate the kinetics of phase I and II reactions in fish. These substrates help to characterize the catalytic activity of various isoforms of phase I and II enzymes. The $O$-deethylation of 7 ethoxyresorufin (EROD activity) is a model reaction used to study the expression of CYP1A, an inducible

cytochrome P450 isoform in fish (Whyte et al., 2000). Other substrates and their respective phase I activities are used as model compounds as well (e.g. 7-ethoxycoumarin -ECOD-, 7pentoxyresoroufin - PROD -, 7-benzyloxyresoroufin - BROD -); however, the isoforms involved in such activities are either not determined yet in all fish species or represent the expression of different P450 isoforms depending on the species. Resorufin is a phase I metabolite obtained after EROD, that is used as substrate for phase II reactions such as glucuronidation and sulfation (George, 1994). Glutathione-s-transferase activity, an important phase II activity performed to conjugate electrophilic compounds, is commonly assessed using reference substrates such as 1chloro-2,4-dinitrobenzene (CDNB) (Habig et al., 1974; George, 1994).

The purpose of this study was to compare the kinetics of specific phase I and II biotranformation reactions among 8 different finfish species of importance in the United States and around the world using the specific substrates aforementioned.

\section{Materials and methods}




\section{ACCEPTED MANUSCRIPT}

\subsection{Fish handling}

Market-size specimens $(n=8)$ of 8 fish species were obtained from commercial farms. After capture, the fish were sacrificed by cervical transection. The species used for this study were channel catfish (Ictalurus punctatus), rainbow trout (Oncorhynchus mykiss), Atlantic salmon (Salmo salar), red tilapia (Oreochromis sp.), largemouth bass (Micropterus salmoides), striped bass (Morone saxatilis), hybrid striped bass (Morone saxatilis x Morone crysops), and bluegill (Lepomis macrochuris). Atlantic salmon individuals were acclimated at the Center for Veterinary Medicine (FDA - Laurel, MD, USA).

2.2 Microsomes / cytosol preparation and phase I-II assays

Microsomes and cytosol were prepared according to Vodicnik et al. (1981). Protein was measured using the bicinchoninic acid protein assay. All the incubations with either microsomes or cytosolic fractions were performed at room temperature $\left(20^{\circ} \mathrm{C}-22^{\circ} \mathrm{C}\right)$. Ethoxycoumarin-odealkylation (ECOD) kinetics was based on Haasch \& col (1994) and Schlenk \& col. (2000) with some modifications. Reaction mixtures had $50 \mu \mathrm{L}$ of buffer Tris- $\mathrm{HCl}(100 \mathrm{mM}, \mathrm{pH}=7.4), 25 \mu \mathrm{L}$ of microsomes (100 $\mu \mathrm{g}$ of protein), $10 \mu \mathrm{L}$ of 7-ethoxycoumarin (20-100 $\mu \mathrm{M}$ range) and $25 \mu \mathrm{L}$ of NADPH tetrasodium salt $(0.1 \mathrm{mM})$. ECOD activity was calculated based on the relative fluorescence units (RFUs) of the 7-hydroxycoumarin produced $($ excitacion $=380 \mathrm{~nm}$, emission $=$ $460 \mathrm{~nm}$ ) in a microplate absorbance-fluorescence reader (TECAN, Genios ${ }^{\mathrm{TM}}$, Austria). Ethoxyresorufin-o-dealkylation (EROD) (Modified from Eggens and Galgani, 1992; Haasch et al., 1994). Reaction mixtures consisted of $50 \mu \mathrm{L}$ of buffer Tris- $\mathrm{HCl}(100 \mathrm{mM}, \mathrm{pH}=7.4), 25 \mu \mathrm{L}$ of microsomes (100 $\mu \mathrm{g}$ of protein), $10 \mu \mathrm{L}$ of 7-ethoxyresorufin (range $0-2 \mu \mathrm{M}$ ) and $25 \mu \mathrm{L}$ of NADPH (1 mM). EROD was monitored based on the RFUs of the resorufin produced by the reaction $($ excitation $=510 \mathrm{~nm}$, emission $=580 \mathrm{~nm})$. Pentoxyresorufin- $(P R O D)$ and benzyloxyresorufin-o-dealkylation (BROD) activities were assayed following the same protocol as for EROD. A $5 \mu \mathrm{M}$ substrate concentration was tested as the initial concentration point. Phenobarbital-induced rat microsomes were used as a positive control. Glutathione-s-transferase (GST) kinetics was performed according to Habig \& col. (1974). Reaction mixtures consisted of $165 \mu \mathrm{L}$ of $100 \mathrm{mM}$ Tris-HCl buffer ( $\mathrm{pH}=7.4), 7 \mu \mathrm{L}$ of 1 -chloro-2,4-dinitrobenzene (CDNB) (0.1- 


\section{ACCEPTED MANUSCRIPT}

$2.0 \mathrm{mM}$ range), $3.5 \mu \mathrm{L}$ of $60 \mathrm{mM}$ reduced L-glutathione, and $10 \mu \mathrm{g}$ of cytosol. The rate of CDNB conjugation was monitored $(\lambda=340 \mathrm{~nm})$ for 5 minutes. For final calculations a molar absorption coefficient $\left(C=9.6 \mathrm{mM}^{-1} \mathrm{~cm}^{-1}\right)$ was used adjusting the path length to the corresponding 96-well plate volume. UDP-glucuronosyltransferase (UDPGT) kinetics (Modified from Schell and James, 1989). Reaction mixtures consisted of $50 \mu \mathrm{L}$ of phosphate buffer $(\mathrm{pH}=7.4)$ with 0.1 $\%$ Triton X-100 and $10 \mathrm{mM} \mathrm{MgCl} 2,100 \mu \mathrm{g}$ of microsomal protein, $25 \mu \mathrm{L}$ of uridin 5'diphosphoglucuronic acid trisodium salt (UDPGA) and $10 \mathrm{uL}$ of resorufin (1-50 $\mu \mathrm{M}$ range). Sulfotransferase (ST) kinetics (Modified from Schell and James, 1989; Beckmann, 1991). Reaction mixtures consisted of $50 \mu \mathrm{L}$ of phosphate buffer $(\mathrm{pH}=7.4), 100 \mu \mathrm{g}$ of cytosolic protein, $10 \mu \mathrm{L}$ of resorufin (0.5-20 $\mu \mathrm{M}$ range) and $25 \mu \mathrm{L}$ of adenosine 3'-phosphate 5'-phosphosulfate lithium salt (PAPS).

2.3 Calculation of kinetics parameters and statistical analysis

Results on velocity rates for all of the phase I and II enzymes were graphed as Michaelis-Menten (velocity vs. [substrate]) and Lineweaver-Burk (1/velocity vs 1/[substrate]) plots. Maximal velocity $\left(\mathrm{V}_{\max }\right)$, Michaelis-Menten constant $\left(\mathrm{K}_{\mathrm{m}}\right)$ and $\mathrm{V}_{\mathrm{max}} / \mathrm{K}_{\mathrm{m}}$ ratio were derived by regression of the double-reciprocal plots (Cornish-Bowden, 1995). Results are reported as means \pm standard errors. Data sets were analyzed for normality and homogeneity of variances. Data being both normal and homogeneous were compared using one-way ANOVA test (comparison among species) followed by Tukey's mean separation test. SAS (Statistical Analysis Software, Cary, NC, USA) program was used for these data processing. Statistical significance was set at a significance level of $\alpha=0.05$.

\section{Results}

ECOD and EROD kinetics. Channel catfish had the highest ECOD $\mathrm{V}_{\max }$ of all the species followed by Atlantic salmon, rainbow trout, hybrid striped bass and tilapia. This value was significantly different $(\mathrm{p}<0.05)$ from all the others. $\mathrm{K}_{\mathrm{m}}$ was quite similar among Atlantic salmon, rainbow trout, channel catfish and tilapia. Hybrid striped bass $\mathrm{K}_{\mathrm{m}}$ was the highest value of all, being significantly different from the others $(\mathrm{p}<0.05) . \mathrm{V}_{\mathrm{max}} / \mathrm{K}_{\mathrm{m}}$ ratios in ECOD indicated 
that channel catfish and Atlantic salmon were the most efficient species of all (Table 1). Rainbow trout and tilapia had lower $\mathrm{V}_{\max } / \mathrm{K}_{\mathrm{m}}$ ratios and hybrid striped bass had the lowest $\mathrm{V}_{\text {max }} / \mathrm{K}_{\mathrm{m}}$ ratio showing the lowest ECOD efficiency of all the species. Bluegill microsomes did not present any response to 7-ethoxycoumarin. ECOD kinetics in striped bass and largemouth bass were not performed due to insufficient microsomal sample.

EROD kinetics parameters were done for five of the eight species examined in this study. Striped bass, hybrid striped bass and bluegill had very low velocity values (pmols resorufin/min/mg protein) at $1 \mu \mathrm{M}$ 7-ethoxyresorufin $(4.0 \pm 1.0,2.8 \pm 0.3$, and $3.7 \pm 1.0$, respectively). Higher and lower substrate concentration values did not reveal changes in the velocity rate. Atlantic salmon $(66.0 \pm 7.0)$ and tilapia $(74.0 \pm 15.0)$ had the highest $V_{\max }$ of all, followed by channel catfish $(39.0 \pm 7.0)$, rainbow trout $(28.0 \pm 8.0)$ and largemouth bass $(27.0 \pm 8.0)$. As far as $K_{m}$ is concerned, channel catfish $(1.8 \pm 0.5)$ and tilapia $(2.1 \pm 0.3)$ had higher values from those in largemouth bass $(0.9 \pm 0.1)$, rainbow trout $(0.6 \pm 0.07)$ and Atlantic salmon $(0.2 \pm 0.02)(\mathrm{p}<$ 0.05). Atlantic salmon had the highest $\mathrm{V}_{\max } / \mathrm{K}_{\mathrm{m}}$ ratio of this reaction as compared to tilapia, rainbow trout, largemouth bass and channel catfish $(\mathrm{p}<0.05)$ (Table 1).

PROD and BROD kinetics. None of the fish species showed either PROD or BROD activities when a $5 \mu \mathrm{M}$ substrate concentration was tested for both alkoxycoumarins. Phenobarbial-induced rat microsomes that were used as positive controls, showed both PROD (23 pmols/ min / mg protein) and BROD (183 pmols / min / mg protein) activities.

Glutathione-s-transferase kinetics. The highest GST capacity was obtained for tilapia and Atlantic salmon, followed by rainbow trout, channel catfish and largemouth bass. The lowest $\mathrm{V}_{\max }$ values $(\mathrm{p}<0.05)$ were found in striped bass, hybrid striped bass and bluegill. As for $\mathrm{K}_{\mathrm{m}}$, channel catfish and striped bass showed the lowest values followed by bluegill, tilapia, and hybrid striped bass. The highest $\mathrm{K}_{\mathrm{m}}$ values were found in largemouth bass, rainbow trout and Atlantic salmon (Table 2). $V_{\max } / \mathrm{K}_{\mathrm{m}}$ ratios indicate that channel catfish and tilapia had the most efficient GST activity towards the substrate. Atlantic salmon and rainbow trout had lower ratios whereas striped bass, largemouth bass, bluegill and hybrid striped bass had the lowest GST efficiencies of all. 
UDP-glucuronosyltransferase kinetics. UDPGT activity was expressed as pmols resorufin/min/ mg protein. Rainbow trout $(930 \pm 258)$ and Atlantic salmon $(410 \pm 86)$ had the highest UDPGT $\mathrm{V}_{\max }$ values of all the species. On the other hand, channel catfish microsomes did not have a UDPGT-based conjugation activity towards resorufin. Values for tilapia (368 \pm 89 ), largemouth bass (273 \pm 16$)$, hybrid striped bass $(271 \pm 37)$, bluegill $(263 \pm 31)$ and striped bass $(231 \pm 29)$ were quite similar and not significantly different from each other $(\mathrm{p}>0.05) . \mathrm{K}_{\mathrm{m}}(\mu \mathrm{M})$ values were quite similar among the 7 species tested, ranging from $17.5 \pm 2.3$ to $36.0 \pm$ 7.0. As for $\mathrm{V}_{\max }$ / $\mathrm{K}_{\mathrm{m}}$ ratios, rainbow trout $(30.4 \pm 4.4)$ and Atlantic salmon $(18.5 \pm 3.3)$ had the highest values of all the species. Bluegill $(16.3 \pm 3.1)$, tilapia $(15.0 \pm 3.0)$ and largemouth bass $(11.0 \pm 1.0)$ had lower ratios than Atlantic salmon and rainbow trout. Striped bass $(8.4 \pm 1.0)$ and hybrid striped bass $(8.2 \pm 0.9)$ had the lowest efficiency ratios for this reaction (Table 2$)$.

Sulfotransferase kinetics. Values were expressed as pmols resorufin/min/mg protein. Tilapia $(328.0 \pm 17.0)$ and channel catfish $(265.0 \pm 27.0)$ had the highest conjugation velocities followed by Atlantic salmon (215.0 \pm 14.0$)$, rainbow trout (190.0 \pm 20.0$)$ and largemouth bass (147.0 \pm 10.0). Bluegill (107.0 \pm 23.0$)$, hybrid striped bass $(46.6 \pm 4.0)$ and striped bass $(45.0 \pm 5.0)$ had again the lowest $\mathrm{V}_{\max }$ value of all the species. $\mathrm{K}_{\mathrm{m}}$ were very similar among all the species (range $0.3 \pm 0.1$ to $1.0 \pm 0.2)$ with the exception of striped bass which had the lowest values of all $(0.1$ $\pm 0.03) . V_{\max } / K_{m}$ ratios for $S T$ activity indicated that Atlantic salmon (435.5 \pm 63.0$)$ had the best enzymatic efficiency followed by channel catfish $(388.0 \pm 63.0)$, striped bass $(384.0 \pm 70.0)$, tilapia (354.0 \pm 64.0$)$, hybrid striped bass $(309.9 \pm 89.0)$, largemouth bass $(300.0 \pm 83.0)$ and rainbow trout $(287.0 \pm 18.8)$. Bluegill $(167.0 \pm 35.0)$ had the lowest ratio of all (Table 2$)$.

For comparison purposes, Figure 1 shows the phase I and phase II reactions that were studied in the present work for the eight species.

\section{Discussion}

The present study was intended to compare the baseline kinetics of phase I and II biotransformation reactions among eight different fish species. Comparisons between present results and other studies were relatively difficult in some cases given that most of the 
investigations have dealt with catalytic activities at saturating conditions of substrates instead of full kinetics working a range of substrate concentrations.

ECOD and EROD kinetics. ECOD has been studied in mammals as a marker activity of CYP1A1, CYP1A2 CYP2B1, CYP2E1, and CYP2E6 (Yun et al., 1991; Yamazaki et al., 1996). In fish, the catalysts of 7-ethoxycoumarin are still unknown; nevertheless, this reaction is apparently catalyzed in rainbow trout by the CYP1A (Cravedi et al., 1998). Among the inducers of ECOD activity in fish species are Aroclor 1254 (a PCBs mixture) (Elcombe \& Lech, 1979) and $\beta$-naphthoflavone (Haasch et al., 1994) in rainbow trout; and 3-methylcholanthrene and PCBs in tilapia (niloticus x aureus) (Ueng et al., 1992; Ueng \& Ueng, 1995). Most of these compounds have also been found to be inducers of EROD activity. On the other hand, there is substantial ECOD activity in non-CYP1A induced channel catfish, suggesting and additional constitutive role (Perkins, 1999; Perkins et al., 2000). In the present study, channel catfish had the highest ECOD velocity and catalytic efficiency of all the species. This velocity doubled the values in Atlantic salmon, rainbow trout, tilapia, and hybrid striped bass. Despite these differences, all the values were quite similar to those in non-induced fish. $\mathrm{V}_{\max }$ in channel catfish (108.0 $\pm 6.9 \mathrm{pmols}$ 7-hydroxycoumarin/min/mg protein) was quite similar to the value found by Perkins (1999) (109.0 \pm 3.0$)$. ECOD for rainbow trout (42.1 pmols $/ \mathrm{min} / \mathrm{mg}$ protein) was lower than the one reported by Kleinow et al. (1990) in the same species ( $80 \mathrm{pmols} / \mathrm{min} / \mathrm{mg}$ protein). The $\mathrm{V}_{\max }$ values found for tilapia (32.0 $\pm 0.9 \mathrm{pmols}$ 7-hydroxycoumarin/min/mg protein) is below the ones reported in other studies. Ueng \& col. (1992) and Ueng \& Ueng (1995) found $143.0 \pm$ 27.0 and $311.0 \pm 38.0$ pmols 7-hydroxycoumarin/min/mg protein for ECOD activity in noninduced tilapia weighing 200-300 grams. These values are between 2 and 5-fold higher than the corresponding in the present work. These investigators performed ECOD assays at $37^{\circ} \mathrm{C}$ while our incubations were performed at room temperature $\left(20-21^{\circ} \mathrm{C}\right)$. This factor may partially explain such differences between the studies.

EROD activity has been studied in over 150 fish species. This activity is mainly examined to determine its suitability as a biomarker of pollution (Whyte et al., 2000). In the present study, EROD $V_{\max }$ values were quite similar among the species. Despite differences among some of them, all values were below $100 \mathrm{pmols} / \mathrm{min} / \mathrm{mg}$ protein. Hybrid striped bass, striped bass and 
bluegill showed the lowest velocities. Changes in phase I reactions have been reported after drug use in aquacultured species. ECOD and EROD activities were significantly inhibited by enrofloxacin, a fluoroquinole antibiotic, after in vivo treatment in sea bass (Dicentrarchus labrax) (Vaccaro et al., 2003). In a different study by our group, the inducing effects on EROD activity $(2.2-2.6$ fold $)$ was found after in vivo treatment of channel catfish with albendazole at therapeutic dosage (unpublished data, in revision). This suggests that knowing baseline alkoxyresorufins and alkoxycoumarins activities in fish species may help to predict effects due to some drug treatments in aquacultured finfish species.

PROD and BROD kinetics. The present results indicate that none of the fish species was reactive to either of these two alkoxyphenoxazones. Haasch and col. (1994) reported that sham-injected rainbow trout had no PROD activity and negligible BROD activity $(1.1 \mathrm{pmols}$ resorufin/min/mg protein). Although no P450 isoform(s) has been identified in fish as responsible for PROD and/or BROD activities, inducing effects such as the ones exerted by isosafrole, $\beta-\mathrm{NF}$ and dexametasone in rainbow trout may help to differentiate between the expected baseline values, such as the ones found in our study, and a possible induction after exposure to contaminants or drugs.

Glutathion-s-transferase kinetics. GST activity is an indicator of conjugation of electrophilic compounds with glutathione (GSH), a cytosolic tripeptide in milimolar concentrations within the cell. These electrophilic compounds that are conjugated by GSH may exert adverse changes on macromolecules (e.g. proteins, lipids) within the cell structure (Stephensen et al., 2002). $\mathrm{V}_{\max }, \mathrm{K}_{\mathrm{m}}$ and $\mathrm{V}_{\mathrm{max}} / \mathrm{K}_{\mathrm{m}}$ for $\mathrm{CDNB}$ conjugation were significantly different among the species in the present study. Interestingly, Atlantic salmon had one of the highest $\mathrm{V}_{\max }$ and $\mathrm{K}_{\mathrm{m}}$ values. On the other hand, channel catfish presented the lowest $\mathrm{K}_{\mathrm{m}}$ of all the species. Channel catfish and tilapia are among the species with the highest GST-mediated conjugation of CDNB. Juveniles of channel catfish kept in free-flowing tanks had high CDNB conjugation velocities ranging from 1325 (Gallagher et al., 1996) to $1500 \mathrm{nmols} / \mathrm{min} / \mathrm{mg}$ protein (Gallagher and Di Giulio, 1992). Ankley \& Agosin (1987) reported $827 \mathrm{nmols} \mathrm{CDNB} / \mathrm{min} / \mathrm{mg}$ protein in channel catfish that were maintained for 9 to 16 months in fiberglass tanks. These values are higher than the maximum velocities found in the present study $(657 \pm 39 \mathrm{nmols} / \mathrm{min} / \mathrm{mg}$ protein $)$. Pathiratne and George 
(1996) reported high GST activity in tilapia (Oreochromis niloticus) (1900 $\pm 120 \mathrm{nmols} / \mathrm{min} / \mathrm{mg}$ protein) using CDNB as a substrate. In the present study, tilapia had the highest $\mathrm{V}_{\max }$ of all the species (1508 $\pm 70 \mathrm{nmols} / \mathrm{min} / \mathrm{mg}$ protein) and the second highest catalytic efficiency $\left(\mathrm{V}_{\max } / \mathrm{K}_{\mathrm{m}}\right)$ after channel catfish. GST activity has been considered of great importance in detoxification of electrophilic xenobiotics (Shailaja \& D'Silva, 2003). Some authors have reported that a lower incidence of tumors after exposure to carcinogenic compounds such as PAH's, PCB's, and other environmental hepatocarcinogens in channel catfish may result from the notable GST activity found in this species (Gallagher et al., 1996). Tilapia has also been reported as a species with high GST-based conjugation (Gadagbui et al., 1996; Shailaja \& D’Silva, 2003). Reports on CDNB conjugation in rainbow trout, largemouth bass, Atlantic salmon and bluegill indicate lower capacity as compared to channel catfish and tilapia. In rainbow trout, reports show a wide range of activity: $700 \pm 80 \mathrm{nmols} / \mathrm{min} / \mathrm{mg}$ protein (Pérez-López et al., 2000), $348 \pm 17$ nmols/min/mg protein (Laurén et al., 1989), and $183 \pm 17$ nmols/min/mg protein (Otto \& Moon, 1996). Our study showed a $V_{\max }$ value of $929 \pm 65$ (nmols/min/mg potein) which is higher than the one found by Pérez-López and col. (2000). Largemouth bass showed in the present study a $\mathrm{V}_{\max }$ value of $589 \pm 52 \mathrm{nmols} / \mathrm{min} / \mathrm{mg}$ protein which is lower than the one reported by Gallagher and collaborators (2000) in a full kinetic study (843 - $1154 \mathrm{nmols} / \mathrm{min} / \mathrm{mg}$ protein). GST activity has been of particular interest in this species given the high risk of exposure to pollutants that are detoxified through GSTs and its predatory habits (Gallagher et al., 2000; Pham et al., 2002). Largemouth bass had in the study by Pham and collaborators (2002) one of the highest, GSTmediated 4-hydroxynonenal (4HNE) conjugation which was a good indicator of protection against peroxidation of polyunsaturated fatty acids in the liver. However, largemouth bass had in the present study a lower capacity towards CDNB than tilapia, channel catfish, and rainbow trout. As for Atlantic salmon, a study in immature ( $60 \mathrm{~g}$ in weigh) juveniles reports a CDNB conjugation of $290 \pm 8 \mathrm{nmols} / \mathrm{min} / \mathrm{mg}$ protein (Nóvoa-Valiñas et al., 2002). CDNB conjugation kinetics was studied in our research using Atlantic salmon ranging from 492 to $1000 \mathrm{~g}$. Maximum velocity in this species was one of the highest of all $(1349 \pm 107 \mathrm{nmols} / \mathrm{min} / \mathrm{mg}$ potein) but so was enzyme affinity $(0.5 \pm 0.10 \mathrm{mM})$, yielding a lower catalytic efficiency $(2816 \pm$ 329) than channel catfish and tilapia. 
UDP-glucuronosyltransferase (UDPGT) kinetics. Glucuronidation is one of the major phase II pathways in fish and other species (Kasper and Henton, 1980; Clarke et al., 1991). Both endogenous (e.g., bilirubin, steroids, thyroid hormones, etc.) and exogenous compounds (e.g., PCBs, pesticides, drugs, etc.) are conjugated with glucuronic acid via UDPGTs (George, 1994). Among the drugs and pesticides that are conjugated via UDPGTs are chloramphenicol (Cravedi et al., 1985), organophosphates (Takimoto et al., 1987), and phenols (Lech, 1973; Kane et al., 1994). Aflatoxicol B1 glucuronide is also formed in rainbow trout exposed to this hepatocarcinogen (Loveland et al., 1984). Kinetics of UDPGT activity in the present study showed lower variability among the species as compared to the phase I reactions and the GSTmediated conjugation. With the exception of striped bass, largemouth bass and hybrid striped bass, the other species had quite similar results. In the past, differences in UDPGT -based conjugation have helped to understand distinct sensitivities among fish species to pollutants or drugs. Kane et al. (1994) found that the lower $\mathrm{V}_{\mathrm{max}} / \mathrm{K}_{\mathrm{m}}$ ratio in sea lamprey (Petromyzon marinus) as compared to channel catfish, rainbow trout and bluegill helped to explain a high sensitivity to 3-trifluoromethyl-4-nitrophenol (TFM), due to lower UDPGT-based conjugation.

Sulfotransferase kinetics. Sulfation is catalyzed by sulfotransferases (ST), a group of cytosolic enzymes that have lower capacity than UDPGTs but a higher affinity for the substrates (Parkinson, 2001). Some studies have identified ST activity towards thyroid hormones in plaice (Osborn and Simpson, 1969) and rainbow trout (Finnson and Eales; 1997, 1998). The effects of environmental estrogens and other endocrine disrupters on ST-mediated conjugation have been studied showing additional implications of these pollutants on biotransformation capabilities (Nishiyama et al., 2002; Kirk et al., 2003; Ohkimoto et al., 2003). The present work corroborated that STs are lower capacity / higher affinity enzymes in comparison to UDPGTs. $\mathrm{V}_{\max }$ values for ST in all the species were several times lower than the corresponding values for UDPGT. On the other hand, the low $\mathrm{K}_{\mathrm{m}} \mathrm{s}$ indicated the higher binding affinities of ST in comparison to the high values for UDPGT (lower affinities).Interestingly, channel catfish microsomes were not reactive to 7-ethoxyresorufin for UDPGCT-based conjugation. However, cytosolic fractions of the same specimens responded to ST conjugation. ST-mediated conjugation of 7-ethoxyresorufin was one of the assays with the lowest variation among the species studied in this investigation. $\mathrm{V}_{\max } / \mathrm{K}_{\mathrm{m}}$ ratios did not show significant differences amongst them. However, $\mathrm{V}_{\max }$ values were 


\section{ACCEPTED MANUSCRIPT}

significantly higher for rainbow trout, tilapia, channel catfish, Atlantic salmon and largemouth bass. The lowest capacities were found in striped bass, hybrid striped bass and bluegill. Catalytic efficiencies were quite similar among the species due to higher binding affinities in the three species that had the lowest capacities $\left(\mathrm{V}_{\max }\right)$.

\section{Conclusions}

Based on the catalytic probes that were used in this study to evaluate some phase I and II biotransformation reactions, the 8 fish species that were investigated exhibited differences among them. Channel catfish, tilapia, rainbow trout and Atlantic salmon had the maximum capacities and the highest catalytic efficiencies for most of these catalytic probes. Hybrid striped bass, striped bass and bluegill displayed the lowest efficiencies. Largemouth bass was in between the two suggested groups, showing higher capabilities in some tests and lower in others.

In some cases, species that displayed low biotransformation capabilities (e.g. low $\mathrm{V}_{\max }$ ), had similar catalytic efficiencies than the ones with highest maximun velocities due to a higher binding affinity (e.g. low $\mathrm{K}_{\mathrm{m}}$ ) of their enzymatic systems. This was particularly evident for the UDPGT and ST reactions.

Major differences found in this study among the species with regard to GST-based biotransformation may help to understand their particular susceptibility or resistance to electrophilic compounds that exert deleterious effects on macromolecules within the cell. Channel catfish and tilapia exhibited the highest capacity and efficiency in GST-mediated conjugation. Striped bass, hybrid striped bass and bluegill had very poor GST-based conjugation of CDNB.

\section{Acknowledgements}

This work was funded by the Joint Institute of Food Safety and Nutrition (JIFSAN) - Contract \# FDU001418. The authors thank Charlie Gieseker and Stanley Serfling for their help with the acclimation of Atlantic salmon at the Center for Veterinary Medicine (FDA). 


\section{ACCEPTED MANUSCRIPT}

\section{References}

Ankley, G.T., Agosin, M., 1987. Comparative aspects of hepatic UDP-glucuronosyltransferases and glutathione-s-transferases in bluegill and channel catfish. Comp. Biochem. Physiol. B 87, 671-673.

Arukwe, A., Nordtug, T., Kortner, T.M., Mortensen, A.S., Brakstad, O.G. 2008. Modulation of steroidogenesis and xenobiotic biotransformation responses in zebrafish (Dario rerio) exposed to water-soluble fraction of crude oil. Environ. Res. 107, 362-370.

Beckmann, J.D., 1991. Continuous fluorometric assay of phenol sulfotransferase. Anal. Biochem. 197, 408-411.

Clarke, D.J., George, S.G., Burchell, B., 1991. Glucuronidation in fish. Aquat. Toxicol. 20, 3556.

Cornish-Bowden, A., 1995. Fundamentals of enzyme kinetics. Portland Press. London, pp. 55-72.

Cravedi, J.P., Heuillet, G., Peleran, J.C., Wal, J.M., 1985. Disposition and metabolism of chloramphenicol in trout. Xenobiotica 15, 115-121.

Cravedi, J.P., Perdu-Durand, E., Paris, A., 1998. Cytochrome P450-dependent metabolic pathways and glucuronidation in trout liver slices. Comp. Biochem. Physiol. C 121, 267-275.

Eggens, M.L., Galgani, F., 1992. Ethoxyresorufin-o-deethylase (EROD) activity in flatfish: fast determination with a fluoresecence plate reader. Mar. Environ. Res. 33, 213-221.

Elcombe, C.R., Lech, J.J., 1979. Induction and characterization of hemoproteins P450 and monooxygenation in rainbow trout, Salmo gairdneri. Toxicol. Appl. Pharmacol. 49, 437-450.

Finnson, K.W., Eales, J.G., 1997. Glucuronidation of thyroxine and 3,5,3'-triiodothyronine by hepatic microsomes in rainbow trout, Oncorhynchus mykiss. Comp. Biochem. Physiol. C 117, 193-199.

Finnson, K.W., Eales, J.G., 1998. Sulfation of thyroid hormones by liver of rainbow trout, Oncorhynchus mykiss. Comp. Biochem. Physiol. C 120, 415-420.

Gadagbui, B., Addy, M., Goksøyr, A., 1996. Species characteristics of hepatic biotransformation enzymes in two tropical freshwater teleosts, Tilapia (Oreochromis niloticus) and mudfish (Clarias anguillaris). Comp. Biochem. Physiol. C 114, 201-211.

Gallagher, E.P., Di Giulio, R.T., 1992. A comparison of glutathione-dependent enzymes in liver, gills and posterior kidney of channel catfish (Ictalurus punctatus). Comp. Biochem. Physiol. C $102,543-547$. 
Gallagher, E.P., Sheehy, K.M., Lame, M.W., Segall, H.J., 2000. In vitro kinetics of hepatic glutathione S-transferase conjugation in largemouth bass and brown bullheads. Environ. Toxicol. Chem. 19, 319-326.

Gallagher, E.P., Stapleton, P.L., Slone, D.H., Schlenk, D., Eaton, D.L., 1996. Channel catfish glutathione-s-transferase isoenzyme activity toward ( \pm )-anti-benzo[a]pyrene-trans-7,8dihydrodiol-9,10-epoxide. Aquat. Toxicol. 34, 135-150.

George, S. 1994. Enzymology and molecular biology of phase II xenobiotic-conjugating enzymes in fish. In: Marlins, D.C., Ostrander, G.K. (Eds.), Aquatic Toxicology: molecular, biochemical, and cellular perspectives, Lewis Publishers, Boca Raton, Fl., pp. 27-86.

Haasch, M.L., Graf, W.K., Quardokus, E.M., Mayer, R.T., Lech, J.J., 1994. Use of 7alkoxyphenoxazones, 7-alkyloxycoumarins and 7-alkoxyquinolines as fluorescent substrates for rainbow trout hepatic microsomes after treatment with various inducers. Biochem. Pharmacol. 47, 893-903.

Habig, W.H., Pabst, M.J., Jakoby, W.B., 1974. Glutathione S-transferases: the first enzymatic step in mercapturic acid formation. J. Biol. Chemist. 249, 7130-7139.

Kane, A.S., Kahng, M.W., Reimschuessel, R., Nhamburo, P.T., Lipsky, M.M., 1994. UDPglucuronosyltransferase kinetics for 3-trifluoromethyl-4-nitrophenol (TFM) in fish. Trans. Am. Fish. Soc. 123, 217-222.

Kasper, C.B., Henton, D., 1980. Glucuronidation. In: Jacoby, W.B. (Ed.), Enzymatic basis of detoxification Vol II, Academic Press, New York, pp. 3-36.

Kirk, C.J., Bottomley, L., Minican, N., Carpenter, H., Shaw, S., Kohli, N., Winter, M., Taylor, E.W., Waring, R.H., Michelangeli, F., Harris, R.M., 2003. Environmental endocrine disrupters dysregulate estrogen metabolism and $\mathrm{Ca}^{2+}$ homeostasis in fish and mammals via receptorindependent mechanisms. Comp. Biochem. Physiol. A 135, 1-8.

Kleinow, K., Haasch, M.L., Williams, D.E. Lech, J.J. 1990. A comparison of hepatic P450 induction in rat and trout (Oncorhynchus mykiss): delineation of the site of resistance of fish to phenobarbital-type inducers. Comp. Biochem. Physiol. C 96, 259-270.

Laurén, D.J., Halarnkar, P.P., Hammock, B.D., Hinton, D.E., 1989. Microsomal and cytosolic epoxide hydrolase and glutathione S-transferase activities in the gill, liver, and kidney of the rainbow trout, Salmo gairdneri. Baseline levels and optimization of assay conditions. Biochem. Pharmacol. 38, 881-887.

Lech, J.J., 1973. Isolation and identification of 3-trifluoromethyl-4-nitrophenol glucuronide from bile of rainbow trout exposed to 3-fluromethyl-4-nitrophenol. Toxicol. Appl. Pharmacol. 24, 114124. 
Loveland, P.M., Nixon, J.E., Bailey, G.S., 1984. Glucuronides in bile of rainbow trout (Salmo gairdneri) injected with $\left[{ }^{3} \mathrm{H}\right]$ aflatoxin $\mathrm{B} 1$ and effects of dietary $\beta$-naphthoflavone. Comp. Biochem. Physiol. C 78, 13-19.

Mansui, D., 1998. The great diversity of reactions catalyzed by cytochromes P450. Comp. Biochem. Physiol. C 121, 5-14.

Mortensen, A.S., Arukwe, A. 2007. Effects of 17 a-ethynylestradiol on hormonal responses and xenobiotic biotransformation system of Atlantic salmon (Salmo salar). Aquatic Toxicol. 85, 113123.

Nelson, D.R., 1998. Metazoan cytochrome P450 evolution. Comp. Biochem. Physiol. C 121, 1522.

Nishiyama, T., Ogura, K., Nakano, H., Kaku, T., Takahashi, E., Ohkubo, Y., Sekine, K., Hiratsuka, A., Kadota, S., Watabe, T., 2002. Sulfation of environmental estrogens by cytosolic human sulfotransferases. Drug Metabol. Pharmacokin. 17, 221-228.

Nóvoa-Valiñas, M.C., Pérez-López, M., Melgar, M.J., 2002. Comparative study of purification and characterization of the cytosolic glutathione S-transferases from two salmonid species: Atlantic salmon (Salmo salar) and brown trout (Salmo trutta). Comp. Biochem. Physiol. C 131, 207-213.

Ohkimoto, K., Sughara, T., Sakakibara, Y., Suizo, M., Liu, M-Y., Carter, G., Liu, M-C., 2003. Sulfonation of environmental estrogens by zebrafish cytosolic sulfotransferases. Biochem. Biophys. Res. Comun. 309, 7-11.

Osborn, R.H, Simpson, T.H., 1969. Thyroxine metabolism in plaice, Pleuronectes platessa. Gen. Comp. Endocrinol. 13, 524.

Otto, D.M.E., Moon, T.W., 1996. Phase I and II enzymes and antioxidant responses in different tissues of brown bullheads from relatively polluted and non-polluted systems. Arch. Environ. Contam. Toxicol. 31, 141-147.

Parkinson, A. 2001. Biotransformation of xenobiotics. In: Klaassen, C.D. (Ed.), Casarett \& Doull's Toxicology, $6^{\text {th }}$ ed., McGraw-Hill, New York, pp. 133-224.

Pathiratne, A., George, S. 1996. Comparison of xenobiotic metabolizing enzymes of tilapia with those of other fish species and interspecies relationships between gene families. Mar. Environ. Res. 42, 293-296.

Pérez-López, M., Anglade, P., Bec-Ferté, M.P. 2000. Characterization of hepatic and extrahepatic glutathione-s-transferases in rainbow trout (Oncorhynchus mykiss) and their induction by 3,3',4,4'-tetrachlorobiphenyl. Fish Physiol. Biochem. 22, 21-32. 
Perkins, E.J., 1999. Characterization of the hepatic cytochrome P450 monooxygenase system and its role in the metabolism, toxicokinetics, and toxicity of aldicarb in channel catfish (Ictalurus punctatus). University of Mississippi, Oxford (MS):Ph.D. Dissertation.

Perkins, E.J., DeBusk, B.C., Schlenk, D., 2000. Isolation of a novel hepatic CYP2-related protein from channel catfish, Ictalurus punctatus. Fish Physiol. Biochem. 22, 199-206.

Pham, R.T., Gardner, J.L., Gallagher, E.P., 2002. Conjugation of 4-hydroxynonenal by largemouth bass (Micropterus salmoides) glutathione S-transferases. Mar. Environ. Res. 54, 291295.

Reynaud, S., Raveton, M.., Ravanel, P. 2008. Interactions between immune and biotransformation systems in fish: a review. Aquatic Toxicol. 87, 139-145.

Schell, J.D. Jr, James, M.O., 1989. Glucose and sulfate conjugation of phenolic compounds by the spiny lobster (Panulirus argus). J. Biochem. Toxicol. 4, 133-138.

Schlenk, D., DeBusk, B., Perkins, E.J., 2000. 2-methylisoborneol disposition in three strains of catfish: absence of biotransformation. Fish Physiol. Biochem. 23, 225-232.

Shailaja, M.S., D'Silva, C., 2003. Evaluation of impact of PAH on a tropical fish, Oreochromis mossambicus using multiple biomarkers. Chemosphere 53, 835-841.

Stephensen, E., Sturve, J., Förlin, L., 2002. Effects of redox cycling compounds on glutathione content and activity of glutathione-related enzymes in rainbow trout liver. Comp. Biochem. Physiol. C 133, 435-442.

Takimoto, T., Oshima, M., Miyamato, J., 1987. Comparative metabolism of fenitrothion in aquatic organisms. I. Metabolism in the euryhaline fish, Oryzias latipes and Mugil cephalus. Ecotoxicol. Environ. Saf. 13, 104-117.

Ueng, T.H., Ueng, Y.F., Park, S.S., 1992. Comparative induction of cytochrome P450-dependent monooxygenases in the livers and gills of tilapia and carp. Aquat. Toxicol. 23, 49-64.

Ueng, Y.F, Ueng, T.H., 1995. Induction and purification of cytochrome P4501A1 from 3methylcholanthrene-treated tilapia, Oreochromis niloticus x Oreochromis aureus. Arch. Biochem. Biophys. 322, 347-356.

Vaccaro, E., Giorgi, M., Longo, V., Mengozzi, G., Gervasi, P.G., 2003. Inhibition of cytochrome P450 enzymes by enrofloxacin in the sea bass (Dicentrarchus labrax). Aquat. Toxicol. 62, 27-33.

Vodicnik, M.J., Elcombe, C.R., Lech, J.J., 1981. The effect of various types of inducing agents on hepatic microsomal monooxygenase activity in rainbow trout. Toxicol. Appl. Pharmacol. 59, 364-374.

Whyte, J.J., Jung, R.E., Schmitt, C.J., Tillitt, D.E., 2000. Ethoxyresorufin-O-deethylase (EROD) activity in fish as a biomarker of chemical exposure. Crit. Rev. Toxicol. 30, 347-570. 
Yamazaki, H., Inoue, K., Mimura, M., Oda, Y., Guenguerich, F.P., Shimada, T., 1996. 7ethoxycoumarin O-deethylation catalyzed by cytochromes P450 1A2 and 2E1 in human liver microsomes. Biochem. Pharmacol. 51, 313-319.

Yun, C.H., Shimada, T., Guengerich, F., 1991. Purification and characterization of human liver microsomal cytochrome P4502A6. Mol. Pharmacol. 40, 679-685. 


\section{ACCEPTED MANUSCRIPT}

Table 1. $\mathrm{V}_{\max }, \mathrm{K}_{\mathrm{m}}$ and $\mathrm{V}_{\max } / \mathrm{K}_{\mathrm{m}}$ ratios (means $\pm \mathrm{SEM}$ from 3 to 8 samples per species) for ECOD and EROD kinetics in farm-raised fish (different letters in the same column denote statistically significant difference among the species, $\mathrm{p}<0.05)$.

\begin{tabular}{|c|c|c|c|c|c|c|}
\hline \multirow[t]{2}{*}{ Fish species } & \multicolumn{3}{|c|}{ ECOD } & \multicolumn{3}{|c|}{ EROD } \\
\hline & $\mathrm{V}_{\max }$ & $\mathrm{K}_{\mathrm{m}}$ & $\mathrm{V}_{\max } / \mathrm{K}_{\mathrm{m}}$ & $\mathrm{V}_{\max }$ & $\mathrm{K}_{\mathrm{m}}$ & $\mathrm{V}_{\max } / \mathrm{K}_{\mathrm{m}}$ \\
\hline $\begin{array}{l}\text { Channel } \\
\text { catfish }\end{array}$ & $\begin{array}{c}108.0 \pm 7.0 \\
\text { (a) }\end{array}$ & $\begin{array}{l}19.0 \pm 1.2 \\
\text { (a) }\end{array}$ & $\begin{array}{l}5.9 \pm 0.7 \\
\text { (b) }\end{array}$ & $\begin{array}{c}39.0 \pm 7.0 \\
(\mathrm{a}, \mathrm{b})\end{array}$ & $\begin{array}{c}1.8 \pm 0.50 \\
\text { (a) }\end{array}$ & $\begin{array}{l}24 \pm 4 \\
\text { (a) }\end{array}$ \\
\hline $\begin{array}{l}\text { Rainbow } \\
\text { trout }\end{array}$ & $\begin{array}{c}42.0 \pm 2.3 \\
(\mathrm{~b}, \mathrm{c}, \mathrm{d})\end{array}$ & $\begin{array}{l}19.0 \pm 2.5 \\
\text { (a) }\end{array}$ & $\begin{array}{l}2.5 \pm 0.4 \\
\text { (a) }\end{array}$ & $\begin{array}{l}28.0 \pm 8.0 \\
\text { (a) }\end{array}$ & $\begin{array}{c}0.6 \pm 0.07 \\
\quad(a, b)\end{array}$ & $\begin{array}{c}49 \pm 14 \\
\text { (a) }\end{array}$ \\
\hline Tilapia & $\begin{array}{l}32.0 \pm 0.9 \\
\text { (d) }\end{array}$ & $\begin{array}{l}20.3 \pm 3.4 \\
\text { (a) }\end{array}$ & $\begin{array}{c}1.7 \pm 0.3 \\
(\mathrm{a}, \mathrm{c})\end{array}$ & $\begin{array}{l}74.0 \pm 15.0 \\
\text { (b) }\end{array}$ & $\begin{array}{l}2.1 \pm 0.30 \\
\text { (a) }\end{array}$ & $\begin{array}{c}33 \pm 4 \\
\text { (a) }\end{array}$ \\
\hline $\begin{array}{l}\text { Atlantic } \\
\text { salmon }\end{array}$ & $\begin{array}{l}53.0 \pm 1.8 \\
\text { (b) }\end{array}$ & $\begin{array}{l}13.0 \pm 1.4 \\
\text { (a) }\end{array}$ & $\begin{array}{l}4.4 \pm 0.6 \\
\text { (b) }\end{array}$ & $\begin{array}{l}66.0 \pm 7.0 \\
\text { (b) }\end{array}$ & $\begin{array}{c}0.2 \pm 0.02 \\
\text { (b) }\end{array}$ & $\begin{array}{l}300 \pm 28 \\
\text { (b) }\end{array}$ \\
\hline $\begin{array}{l}\text { Largemouth } \\
\text { bass }\end{array}$ & - & - & - & $\begin{array}{l}27.0 \pm 8.0 \\
\text { (a) }\end{array}$ & $\begin{array}{c}0.9 \pm 0.10 \\
(a, b)\end{array}$ & $\begin{array}{l}30 \pm 5 \\
\text { (a) }\end{array}$ \\
\hline $\begin{array}{c}\text { Hybrid } \\
\text { striped bass }\end{array}$ & $\begin{array}{c}36.0 \pm 1.8 \\
(\mathrm{c}, \mathrm{d})\end{array}$ & $\begin{array}{c}120 \pm 39.0 \\
\text { (b) }\end{array}$ & $\begin{array}{l}0.4 \pm 0.1 \\
\text { (c) }\end{array}$ & $2.8 \pm 0.3 \mp$ & - & - \\
\hline Striped bass & - & - & & $4.0 \pm 1.0 \mp$ & - & - \\
\hline Bluegill & $\dagger$ & $\dagger$ & $\dagger$ & $3.7 \pm 1.0 \neq$ & - & - \\
\hline
\end{tabular}

ECOD velocity expressed as pmols 7 hydroxycoumarin/minute/mg protein. EROD velocity as pmols resorufin/minute/mg protein

$\dagger$ : microsomes did not show any activity towards 7-ethoxycoumarin

- ECOD kinetics in striped bass and largemouth bass were nor performed due to insufficient microsomal sample. †: enzyme activity is reported only at $1 \mu \mathrm{M}$ substrate concentration due to very low constitutive levels of activity 
Table 2. $\mathrm{V}_{\max }, \mathrm{K}_{\mathrm{m}}$ and $\mathrm{V}_{\max } / \mathrm{K}_{\mathrm{m}}$ (means $\pm \mathrm{SEM}$ of 3 - 8 samples per species) for glutathione-stransferase (GST), UDP-glucuronosyltransferase (UDPGT) and sulfotransferase (ST) kinetics in farm-raised fish (different letters in the same column denote statistically significant difference among the species, $\mathrm{p}<0.05)$

\begin{tabular}{|c|c|c|c|c|c|c|c|c|c|}
\hline \multirow[t]{2}{*}{ Fish species } & \multicolumn{3}{|c|}{ GST } & \multicolumn{3}{|c|}{ UDPGT } & \multicolumn{3}{|c|}{ ST } \\
\hline & $\mathrm{V}_{\max }$ & $\mathrm{K}_{\mathrm{m}}$ & $\mathrm{V}_{\max } / \mathrm{K}_{\mathrm{m}}$ & $\mathrm{V}_{\max }$ & $\mathrm{K}_{\mathrm{m}}$ & $\mathrm{V}_{\max } / \mathrm{K}_{\mathrm{m}}$ & $\mathrm{V}_{\max }$ & $\mathrm{K}_{\mathrm{m}}$ & $\mathrm{V}_{\max } / \mathrm{K}_{\mathrm{m}}$ \\
\hline $\begin{array}{l}\text { Channel } \\
\text { catfish }\end{array}$ & $\begin{array}{c}657 \pm 39 \\
\text { (c) }\end{array}$ & $\begin{array}{c}0.1 \pm 0.02 \\
\text { (d) }\end{array}$ & $\begin{array}{c}5568 \pm 413 \\
\text { (a) }\end{array}$ & $\dagger$ & $\dagger$ & $\dagger$ & $\begin{array}{c}265 \pm 27 \\
(a, b)\end{array}$ & $\begin{array}{c}0.8 \pm 0.1 \\
\text { (a) }\end{array}$ & $\begin{array}{c}388 \pm 63 \\
(\mathrm{a}, \mathrm{b})\end{array}$ \\
\hline Rainbow trout & $\begin{array}{c}929 \pm 65 \\
\text { (a) }\end{array}$ & $\begin{array}{c}0.4 \pm 0.05 \\
\quad(\mathrm{a}, \mathrm{b})\end{array}$ & $\begin{array}{c}2260 \pm 200 \\
\quad(a, b)\end{array}$ & $\begin{array}{c}930 \pm 258 \\
\text { (a) }\end{array}$ & $\begin{array}{c}32.3 \pm 8.7 \\
\text { (a) }\end{array}$ & $\begin{array}{c}30.4 \pm 4.4 \\
\text { (a) }\end{array}$ & $\begin{array}{c}190 \pm 20 \\
(b, c, d)\end{array}$ & $\begin{array}{l}0.7 \pm 0.1 \\
\text { (a) }\end{array}$ & $\begin{array}{c}287 \pm 18 \\
(\mathrm{a}, \mathrm{b})\end{array}$ \\
\hline Tilapia & $\begin{array}{c}1508 \pm 70 \\
\text { (b) }\end{array}$ & $\begin{array}{c}0.3 \pm 0.01 \\
(\mathrm{a}, \mathrm{b}, \mathrm{c})\end{array}$ & $\begin{array}{c}5005 \pm 23 \\
\text { (a) }\end{array}$ & $\begin{array}{c}368 \pm 89 \\
\text { (b) }\end{array}$ & $\begin{array}{l}28.5 \pm 8.7 \\
\text { (a) }\end{array}$ & $\begin{array}{c}15.4 \pm 2.7 \\
\quad(b, c)\end{array}$ & $\begin{array}{c}328 \pm 17 \\
\text { (a) }\end{array}$ & $\begin{array}{l}1.0 \pm 0.2 \\
\text { (a) }\end{array}$ & $\begin{array}{c}354 \pm 64 \\
(\mathrm{a}, \mathrm{b})\end{array}$ \\
\hline $\begin{array}{l}\text { Atlantic } \\
\text { salmon }\end{array}$ & $\begin{array}{c}1349 \pm 107 \\
\text { (b) }\end{array}$ & $\begin{array}{l}0.5 \pm 0.1 \\
\text { (a) }\end{array}$ & $\begin{array}{c}2816 \pm 329 \\
\quad(\mathrm{a}, \mathrm{b})\end{array}$ & $\begin{array}{c}410 \pm 86 \\
(\mathrm{a}, \mathrm{b})\end{array}$ & $\begin{array}{l}24.0 \pm 6.0 \\
\text { (a) }\end{array}$ & $\begin{array}{c}19.0 \pm 3.0 \\
(\mathrm{a}, \mathrm{b})\end{array}$ & $\begin{array}{c}215 \pm 14 \\
(b, c)\end{array}$ & $\begin{array}{l}0.5 \pm 0.1 \\
\text { (a) }\end{array}$ & $\begin{array}{c}436 \pm 63 \\
\text { (a) }\end{array}$ \\
\hline $\begin{array}{l}\text { Largemouth } \\
\text { bass }\end{array}$ & $\begin{array}{l}589 \pm 52 \\
\text { (c) }\end{array}$ & $\begin{array}{c}0.4 \pm 0.06 \\
(\mathrm{a}, \mathrm{b})\end{array}$ & $\begin{array}{c}1491 \pm 117 \\
\text { (b) }\end{array}$ & $\begin{array}{l}273 \pm 16 \\
\text { (b) }\end{array}$ & $\begin{array}{c}27.0 \pm 3.0 \\
\text { (a) }\end{array}$ & $\begin{array}{c}11.0 \pm 1.0 \\
(\mathrm{~b}, \mathrm{c}, \mathrm{d})\end{array}$ & $\begin{array}{c}147 \pm 10 \\
(\mathrm{c}, \mathrm{d}, \mathrm{e})\end{array}$ & $\begin{array}{l}0.6 \pm 0.1 \\
\text { (a) }\end{array}$ & $\begin{array}{c}300 \pm 83 \\
(a, b)\end{array}$ \\
\hline $\begin{array}{c}\text { Hybrid } \\
\text { striped bass }\end{array}$ & $\begin{array}{c}471 \pm 39 \\
(\mathrm{c}, \mathrm{d})\end{array}$ & $\begin{array}{c}0.4 \pm 0.04 \\
(\mathrm{a}, \mathrm{b}, \mathrm{c})\end{array}$ & $\begin{array}{c}1395 \pm 105 \\
\text { (b) }\end{array}$ & $\begin{array}{c}271 \pm 37 \\
\text { (b) }\end{array}$ & $\begin{array}{c}36.0 \pm 7.0 \\
\text { (a) }\end{array}$ & $\begin{array}{l}8.2 \pm 0.9 \\
\text { (d) }\end{array}$ & $\begin{array}{c}46 \pm 4 \\
\text { (e) }\end{array}$ & $\begin{array}{c}0.3 \pm 0.1 \\
(\mathrm{a}, \mathrm{b})\end{array}$ & $\begin{array}{c}309 \pm 89 \\
(\mathrm{a}, \mathrm{b})\end{array}$ \\
\hline Striped bass & $\begin{array}{l}334 \pm 30 \\
\text { (d) }\end{array}$ & $\begin{array}{c}0.2 \pm 0.02 \\
\quad(\mathrm{c}, \mathrm{d})\end{array}$ & $\begin{array}{c}1525 \pm 99 \\
\text { (b) }\end{array}$ & $\begin{array}{c}231 \pm 29 \\
\text { (b) }\end{array}$ & $\begin{array}{l}29.0 \pm 5.0 \\
\text { (a) }\end{array}$ & $\begin{array}{c}8.4 \pm 1.0 \\
(\mathrm{c}, \mathrm{d})\end{array}$ & $\begin{array}{l}45 \pm 5 \\
\text { (e) }\end{array}$ & $\begin{array}{l}0.1 \pm 0.03 \\
\text { (b) }\end{array}$ & $\begin{array}{c}394 \pm 77 \\
(\mathrm{a}, \mathrm{b})\end{array}$ \\
\hline Bluegill & $\begin{array}{c}354 \pm 26 \\
\text { (d) }\end{array}$ & $\begin{array}{c}0.3 \pm 0.04 \\
(b, c)\end{array}$ & $\begin{array}{c}1394 \pm 145 \\
\text { (b) }\end{array}$ & $\begin{array}{c}263 \pm 31 \\
\text { (b) }\end{array}$ & $\begin{array}{c}17.5 \pm 2.3 \\
\text { (a) }\end{array}$ & $\begin{array}{c}16.3 \pm 3.1 \\
\text { (b) }\end{array}$ & $\begin{array}{c}107 \pm 23 \\
(\mathrm{~d}, \mathrm{e})\end{array}$ & $\begin{array}{l}0.7 \pm 0.1 \\
\text { (a) }\end{array}$ & $\begin{array}{c}167 \pm 35 \\
\text { (b) }\end{array}$ \\
\hline
\end{tabular}

GST velocity expressed as nmols of CDNB/minute/mg protein; UDPGT and ST velocities expressed as pmols resorufin/minute/mg protein

$\dagger$ NO UDPGT activity was detected using resorufin as substrate in channel catfish 
Figure 1. Relative $\mathrm{V}_{\text {max }} / \mathrm{K}_{\mathrm{m}}$ ratio (means $\pm \mathrm{SEM}$ ) for the phase I and II reactions tested in the eight species. Inter-species ratios are relative to each other and the $\mathrm{Y}$-axis scale is provided for the purpose of species comparison only.

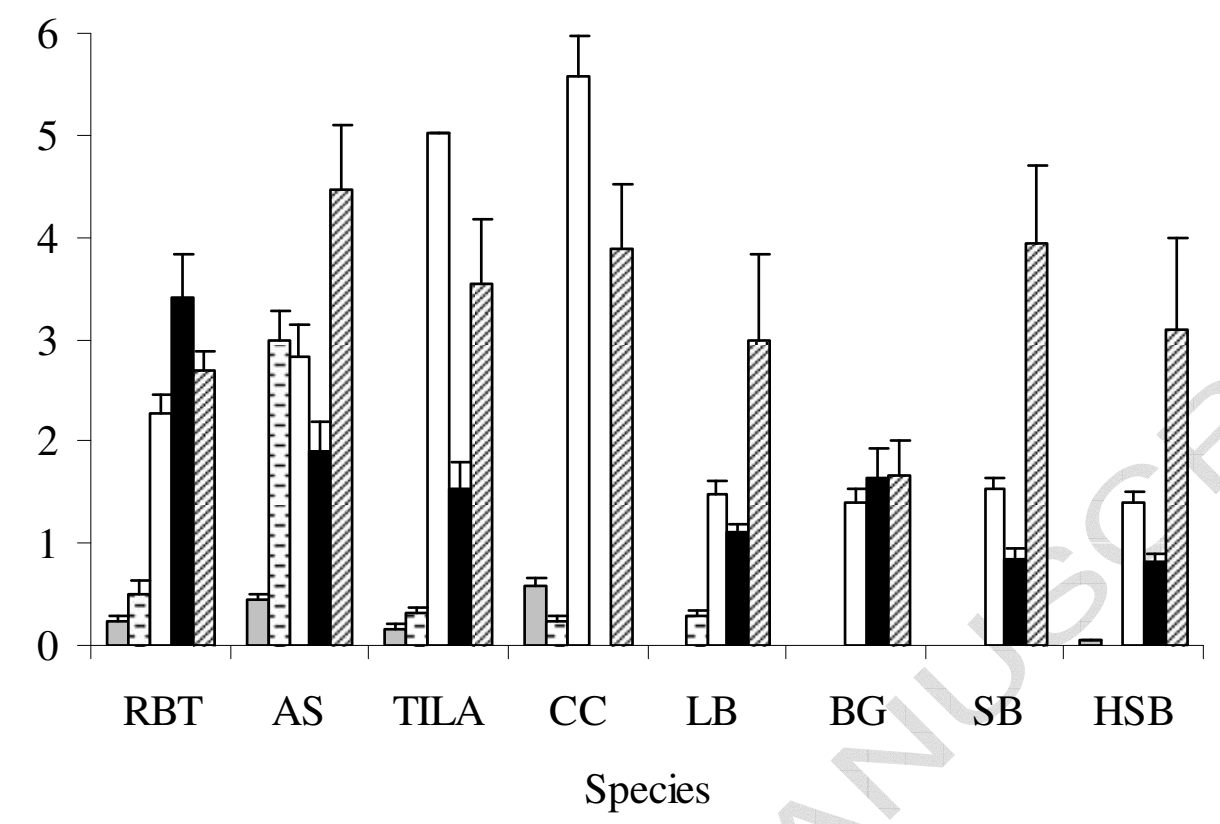

ECOD $\quad$ EROD $\square$ GST $\square$ UDPG $\square \mathrm{ST}$

$\mathrm{RBT}=$ rainbow trout, $\mathrm{AS}=$ Atlantic salmon, TILA = tilapia, $\mathrm{CC}=$ channel catfish, $\mathrm{LB}=$ largemouth bass, $\mathrm{BG}=$ bluegill, $\mathrm{SB}=$ striped bass, HSB = hybrid striped bass. 